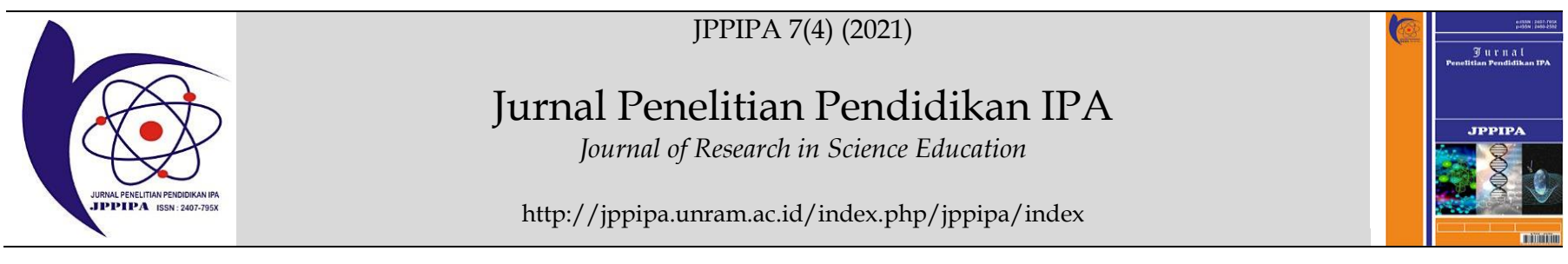

\title{
Development of Discovery Learning-based E-modules Using PDF Flip Professional Software Integrated with the Website as An Alternative to Learning Physics During the Covid 19 Pandemic
}

\author{
Wayan Sudarsana ${ }^{*}$, Sarwanto ${ }^{1}$, Ahmad Marzuki $^{1}$ \\ ${ }^{1}$ Master of Physics Education, Sebelas Maret University, Jl. Ir. Sutami, Kentingan, Surakarta, Indonesia,
}

DOI: $\underline{10.29303 / \text { ippipa.v7i4.786 }}$

\section{Article Info}

Received: July 6th, 2021

Revised: August 13th, 2021

Accepted: September 22th, 2021

\begin{abstract}
This research aims to determine whether the development of discovery learningbased e-module using the professional PDF flip software integrated with the website can be an alternative in learning physics during the COVID-19 pandemic. This type of research is a preliminary study with qualitative descriptive research methods. The instrument used is a questionnaire with four categories, which is then distributed to teachers and students. The subjects in the study were physics teachers and students at SMA Negeri 3 Palu and SMA Karunadipa Palu. The data analysis used a qualitative description of the answer given by teachers and students. The results of preliminary studies show that: COVID-19 pandemic resulted in a look place online so that teachers needed teaching materials and practical media to be used without face-to-face learning. The research concludes that emodule development-based discovery learning using professional PDF flip software is integrated with the website as an alternative in learning physics during the COVID-19 pandemic.
\end{abstract}

Keywords: Need analysis; E-module; COVID-19

Citation: Sudarsana, W., Sarwanto, S., \& Marzuki, A. (2021). Development Of Discovery Learning-based E-modules Using PDF Flip Professional Software Integrated With The Website As An Alternative To Learning Physics During The Covid 19 Pandemic. Jurnal Penelitian Pendidikan IPA, 7(4), 519-524. doi:https://doi.org/10.29303/ippipa.v7i4.786

\section{Introduction}

Physics is a part of science in which knowledge that is systematically organized and organized is obtained based on observations and experiments and is helpful for humans (Aththibby, 2015). Referring to observations and experiments, this shows that studying physics prioritizes the process of obtaining knowledge. Physics learning studies natural phenomena in everyday life and can be used to predict natural phenomena that occur. Learning physics is focused on activities to find information through experience (Desmawati, 2018). They were learning experiences such as observation, problem-solving, and information processing. Therefore, students should be allowed to develop skills in a learning atmosphere. The concept of physics is the ability of students to define and explain in their language the concepts of physics that have been learned without deciphering their true meaning (Hanna et al., 2016)

Physics learning aims to shape student's reasoning abilities through understanding concepts and their relationships so that they can solve physicsrelated problems in everyday life (Neizhela \& Mosik, 2015). Mastering means that learning physics must make students know and memorize concepts, make students understand these concepts, and connect the relationship of a concept with other concepts (Lubis, 2009).

Based on the description above, the essence of physics learning is learning that is carried out to recognize the phenomena that occur in everyday life. Physics studies the physical properties of the

\footnotetext{
*Email: wayansudarsana@student.uns.ac.id
} 
phenomena that occur in everyday life so that it can analyze or describe an event that occurs.

Since the coronavirus or COVID-19 outbreak, the central government has issued a circular about the anticipation of the spread of COVID-19. This requires learning to be carried out online, where students learn from their respective homes without face to face. Students face several difficulties in receiving physics learning material, especially during the Covid period 19 students had to study online, so that media was needed in teaching and learning activities (Saeri, 2020).

One way that can be done for COVID-19 is the use of the internet as a distance learning system via electronic or so-called e-learning. Online learning is a mass learning program with unlimited participants (Mulyadi, 2020). Based on research conducted by (Suryandari \& Burhendi, 2020) regarding a preliminary study of online physics learning during the Covid 19 period, distance learning during the pandemic was not by the needs of e-learning, so it is necessary to develop learning tools as an alternative to learning physics.

An alternative that can be done to overcome the above problems is to develop teaching materials, namely electronic modules. The module is a teaching material used by students to learn well independently where the teacher acts as a facilitator, and there are learning activities (Bakri et al., 2015). The module presents independent and group learning materials that are systematically arranged into learning units to achieve electronic learning objectives, which are presented in an electronic format with animation, audio, navigation so that users are more interactive with the program (Rahmiyati et al., 2018).

The learning module that can be developed for physics learning is developing a physics e-module based on a learning model oriented towards learning in the 21st century, namely discovery learning. The discovery learning model is a learning model that has discovery resources to provide opportunities for students to learn on their own and to solve on their own so that students can develop thinking skills (Sari et al., 2017). The purpose of the discovery learning model is to train students' skills to find and solve problems so that students can analyze and process existing information (Yusuf \& Wulan, 2015). As for using the emodule, students can access the physics e-module through the website so that it can be accessed whenever and wherever they are. Besides, there is an option where the electronic module can be used offline so that students no longer have to rely on the internet network.

Therefore, a preliminary study is needed to see whether E-Module Development Based on Discovery Learning Using Website Integrated Pdf Flip Professional Software can be an alternative in learning physics during the COVID 19 pandemic.

\section{Method}

This preliminary study aims to determine whether E-Module Development Based on Discovery Learning Using Website Integrated PDF Flip Professional Software can be an alternative in learning physics during the COVID-19 pandemic. The method used in this research is a qualitative descriptive research method using a questionnaire distributed to physics teachers and students at SMA Negeri 3 Palu and SMA Karunadipa Palu, then makes a descriptive analysis of the results based on the answers given by respondents from the existing questionnaires. Questionnaires were distributed online via a Google form link to physics teachers and students.

The samples used in this study were physics teachers and students at SMA Negeri 3 Palu SMA and Karunadipa Palu High School. The instrument used is a questionnaire that consists of several statements and questions with four categories.

\section{Result and Discussion}

The results and discussion are based on a preliminary study conducted on discovery learningbased e-module needs analysis using the PDF Flip Professional software integrated on the website as follows:

\section{Needs Analysis for Teachers}

The analysis of teacher needs was conducted by developing questionnaires for five physics teachers from Palu State High School 3 and Karunadipa Palu High School. The questionnaire contains references to the development of e-module physics-based learning inventions using PDF Flip Professional software integrated on the website. Some of the results of the needs analysis for teachers can be seen in Tabel 1 .

Table 1: Physics Teacher Statement Results

\begin{tabular}{|c|c|c|c|c|c|}
\hline \multirow[b]{2}{*}{ No } & \multirow[b]{2}{*}{ Statement } & \multicolumn{4}{|c|}{ Teacher Perspective } \\
\hline & & $\begin{array}{l}\text { Strongly } \\
\text { Disagree }\end{array}$ & Disagree & Agree & $\begin{array}{l}\text { Strongly } \\
\text { Agree }\end{array}$ \\
\hline 1 & In the school where I teach, there is an electronic module to teach & $0(0 \%)$ & $5(100 \%)$ & $0(0 \%)$ & $0(0 \%)$ \\
\hline 2 & $\begin{array}{l}\text { I believe that using electronic modules is more practical in learning } \\
\text { than print modules }\end{array}$ & $0(0 \%)$ & $0(0 \%)$ & $3(60 \%)$ & $2(40 \%)$ \\
\hline
\end{tabular}




\begin{tabular}{|c|c|c|c|c|c|}
\hline \multirow[b]{2}{*}{ No } & \multirow[b]{2}{*}{ Statement } & \multicolumn{4}{|c|}{ Teacher Perspective } \\
\hline & & $\begin{array}{l}\text { Strongly } \\
\text { Disagree }\end{array}$ & Disagree & Agree & $\begin{array}{l}\text { Strongly } \\
\text { Agree }\end{array}$ \\
\hline 3 & $\begin{array}{l}\text { I believe that using electronic modules is more practical in learning } \\
\text { than print modules }\end{array}$ & $0(0 \%)$ & $0(0 \%)$ & $0(0 \%)$ & $5(100 \%)$ \\
\hline 4 & $\begin{array}{l}\text { I believe that using e-modules in learning can solve the problem of } \\
\text { lack of time }\end{array}$ & $0(0 \%)$ & $0(0 \%)$ & $0(0 \%)$ & $5(100 \%)$ \\
\hline 5 & $\begin{array}{l}\text { In its implementation, discovery learning-based e-module using the } \\
\text { PDF flip application will simplify the learning process }\end{array}$ & $0(0 \%)$ & $0(0 \%)$ & $3(60 \%)$ & $2(40 \%)$ \\
\hline 6 & $\begin{array}{l}\text { The website can be used as a medium for learning. Learning using } \\
\text { the internet or the website, not only places learning material for } \\
\text { later access, but the web is also used as an alternative medium of } \\
\text { paper to store documentation (images or videos) and information. I } \\
\text { know that the website is one of the alternative media in learning }\end{array}$ & $0(0 \%)$ & $0(0 \%)$ & $0(0 \%)$ & $5(100 \%)$ \\
\hline 7 & $\begin{array}{l}\text { I believe students will get better learning if they use the web as an } \\
\text { alternative media in learning physics }\end{array}$ & $0(0 \%)$ & $0(0 \%)$ & $\begin{array}{l}5 \\
(100 \%)\end{array}$ & $0(0 \%)$ \\
\hline 8 & $\begin{array}{l}\text { I believe learning to use the web as an alternative media can } \\
\text { improve students' learning abilities }\end{array}$ & $0(0 \%)$ & $0(0 \%)$ & $4(80 \%)$ & $1(20 \%)$ \\
\hline 9 & $\begin{array}{l}\text { I believe that using the web as an alternative media can be easily } \\
\text { used by students without time limits }\end{array}$ & $0(0 \%)$ & $0(0 \%)$ & $0(0 \%)$ & $5(100 \%)$ \\
\hline 10 & $\begin{array}{l}\text { The Covid-19 pandemic requires learning that does not meet real } \\
\text { needs in the classroom. I am sure learning using the web as an } \\
\text { alternative media can be an alternative solution in today's learning }\end{array}$ & $0(0 \%)$ & $0(0 \%)$ & $0(0 \%)$ & $5(100 \%)$ \\
\hline
\end{tabular}

Based on the results of descriptive surveys in Table 1 , the results of statement 1 show that no one answered strongly disagreed $(0 \%) ; 5$ people who responded disapproving (100\%); no one answered agreed $(0 \%)$; And no one answered strongly agree $(0 \%)$. This shows that there is no electronic module used for teaching at each school.

The result of statement 2 shows that the answers given are 0 people for those who answer strongly disagree $(0 \%), 0$ people who answer disagree $(0 \%)$, three people who answered agreed (60\%), and two people who answered strongly agreed (40\%). This shows that most teachers believe using electronic learning modules carried out during the Covid 19 period is more effective.

The result of statement 3 shows that the answers given are 0 people who answer strongly disagree $(0 \%)$, 0 people who answer disagree $(0 \%)$, three people who answered agreed $(60 \%)$, and two people who answered strongly agreed $(40 \%)$. This shows that most teachers believe that using electronic learning modules carried out during the Covid 19 period is more effective.

The result of statement 4 shows that the answers given are 0 people who answer strongly disagree $(0 \%)$, 0 people who answer disagree $(0 \%), 0$ people who answered agreed $(0 \%)$, and five people who answered strongly agreed $(100 \%)$. This shows that the teacher believes that using electronic modules in learning can be a solution to face-to-face learning time due to COVID-19.

The result of statement 5 obtained were 0 people who answered strongly disagree $(0 \%), 0$ people who answered disagree $(0 \%)$, three people who answered agreed $(60 \%)$, and two people who answered strongly agreed $(40 \%)$. This shows that the teacher agrees to use discovery learning-based electronic modules using professional flip PDF software that is easy and practical to use in learning.

The result of statement 6 shows that the answers were 0 people who answered strongly disagree $(0 \%), 0$ people who answered disagree $(0 \%), 0$ people who answered agreed $(0 \%)$, and five people who answered strongly agree $(100 \%)$. This shows that the teacher strongly agrees if the website can be used as an alternative media in learning physics.

The result of statement 7 shows that the answers given are 0 people who answered strongly disagree $(0 \%), 0$ people who answered disagree $(0 \%)$, five people who answered agreed $(100 \%)$, and 0 people who answered strongly agreed $(0 \%)$. This shows that the teacher believes that using an electronic module that is integrated on the website can make learning better.

The result of statement 8 obtained is the answers given, namely, 0 people who answered strongly disagree $(0 \%)$, 0 people answered disagree $(0 \%)$, four people who answered agreed $(80 \%)$, and one person who answered strongly agreed $(20 \%)$. This shows that the teacher agrees that using the website as an alternative media can improve student learning abilities.

The result of statement 9 obtained were the answers given were 0 people who answered strongly disagree $(0 \%), 0$ people answered disagree $(0 \%), 0$ people who answered agreed $(0 \%)$, and five people who answered strongly agreed $(100 \%)$. This shows that the teacher strongly agrees that using the website as an 
alternative media in learning can be used easily by students without time.

The result of statement 10 shows that the answers given are 0 people who answer strongly disagree $(0 \%)$, 0 people who answer disagree $(0 \%), 0$ people answered agree $(0 \%)$, and five people who answered strongly agree $(100 \%)$. This shows that teachers strongly agree that using an electronic module that is integrated with a website in learning can be a solution during the COVID-19 pandemic.

From the results of the statements, it can be seen that almost all teachers agree with learning that uses media in the form of discovery learning-based emodules using professional PDF flip software that is integrated on the website. So, it can be said that it is necessary to develop e-modules because, during the pandemic, media is needed as an alternative in learning. This is supported by research conducted (Abdin et al., 2021) regarding the effectiveness of the google form application as a written test through the ability of students to get an average pretest score of 57.50 and a posttest score of 80.63 an increase occurred.
This can also be seen through the paired t-test, where a significant increase in student learning abilities.

Likewise, research conducted (Matsun \& Saputri, 2020) regarding the development of e-module physics assisted by WhatsApp as an alternative to learning during the COVID-19 pandemic, the level of effectiveness of the module shows that $100 \%$ of students get a higher learning result than the passing score after the e-module.

\section{Needs Analysis for Student}

The needs analysis for students was conducted by providing questionnaires to 32 students of grades $X$ and XI from Palu State High School 3 and Karunadipa Palu High School. The questionnaire contains questions that refer to the relationship to the development of emodule physics-based learning discovery using the web-integrated PDF Flip Professional website software. Some of the results of the needs analysis for students can be seen as follows:

Table 2: The Results of Student Statements

\begin{tabular}{|c|c|c|c|c|c|}
\hline \multirow[b]{2}{*}{ No } & \multirow[b]{2}{*}{ Question } & \multicolumn{4}{|c|}{ Student Perspective } \\
\hline & & $\begin{array}{l}\text { Strongly } \\
\text { Disagree }\end{array}$ & $\begin{array}{l}\text { Do Not } \\
\text { Agree }\end{array}$ & Agree & $\begin{array}{l}\text { Strongly } \\
\text { Agree }\end{array}$ \\
\hline 1 & $\begin{array}{l}\text { Based on the experience you have gone through, do the } \\
\text { teachers use the media in the physics learning process? }\end{array}$ & $\begin{array}{l}0 \\
(0 \%)\end{array}$ & $\begin{array}{l}5 \\
(15.6 \%)\end{array}$ & $\begin{array}{l}28 \\
(87.5 \%)\end{array}$ & $\begin{array}{l}0 \\
(0 \%)\end{array}$ \\
\hline 2 & $\begin{array}{l}\text { Are you interested in the teacher uses the media in the physics } \\
\text { learning process? }\end{array}$ & 0 & $\begin{array}{l}1 \\
(3.1 \%)\end{array}$ & 31 & $\begin{array}{l}1 \\
(3.1 \%)\end{array}$ \\
\hline 3 & $\begin{array}{l}\text { Do you have a module to support the physics learning } \\
\text { process? }\end{array}$ & 0 & $\begin{array}{l}19 \\
(59.4 \%)\end{array}$ & $(37.5 \%)$ & $\begin{array}{l}1 \\
(3.1 \%)\end{array}$ \\
\hline 4 & $\begin{array}{l}\text { In your opinion, can the module make learning practical and } \\
\text { easy to implement? }\end{array}$ & $\begin{array}{l}0 \\
(0 \%)\end{array}$ & $\begin{array}{l}4 \\
(12.5 \%)\end{array}$ & $\begin{array}{l}24 \\
(75 \%)\end{array}$ & $\begin{array}{l}5 \\
(15.6 \%)\end{array}$ \\
\hline 5 & $\begin{array}{l}\text { Based on your experience, have you ever used or utilized the } \\
\text { internet (website) in learning? }\end{array}$ & $\begin{array}{l}0 \\
(0 \%)\end{array}$ & $\begin{array}{l}1 \\
(3.1 \%)\end{array}$ & $\begin{array}{l}23 \\
(71.9 \%)\end{array}$ & $\begin{array}{l}8 \\
(25 \%)\end{array}$ \\
\hline 6 & $\begin{array}{l}\text { Are you interested in the learning process is carried out using } \\
\text { the internet (website)? }\end{array}$ & $\begin{array}{l}0 \\
(0 \%)\end{array}$ & $\begin{array}{l}3 \\
(9.4 \%)\end{array}$ & $\begin{array}{l}21 \\
(65.6 \%)\end{array}$ & $\begin{array}{l}8 \\
(25 \%)\end{array}$ \\
\hline 7 & $\begin{array}{l}\text { Based on experience, do you know or have never used } \\
\text { modules in the learning process? }\end{array}$ & $\begin{array}{l}0 \\
(0 \%)\end{array}$ & $\begin{array}{l}15 \\
(46.9 \%)\end{array}$ & 17 & $\begin{array}{l}1 \\
(3.1 \%)\end{array}$ \\
\hline 8 & $\begin{array}{l}\text { Are you interested in physics learning media with videos, } \\
\text { animations, or simulations to make it easier to understand the } \\
\text { material to be studied? }\end{array}$ & $\begin{array}{l}0 \\
(0 \%)\end{array}$ & $\begin{array}{l}2 \\
(6.3 \%)\end{array}$ & $\begin{array}{l}24 \\
(75 \%)\end{array}$ & $\begin{array}{l}7 \\
(21.9 \%)\end{array}$ \\
\hline
\end{tabular}

Based on the results of descriptive surveys, on question 1, no student answered strongly disagreed $(0 \%)$, five students answered disapproving $(15.6 \%), 28$ people answered agreed $(87.5 \%)$, and 0 people answered strongly agreed $(0 \%)$. This shows that most of the teachers who teach have used learning media in physics subjects.

The students gave to question 2, and the answers were 0 people who answered strongly disagree $(0 \%)$, one person answered disagree $(3.1 \%)$, 31 people who answered agreed $(96.9 \%)$, and one person who answered strongly agreed (3.1\%). This shows that almost all students are interested in the teacher's use of learning media.

The students gave to question 3 , and the answers were 0 people who answered strongly disagree $(0 \%), 19$ people answered disagree $(59.4 \%), 12$ people who answered agreed $(37.5 \%)$, and one person who answered strongly agreed (3.1\%). This shows that more students do not have modules to support learning.

The students gave to question 4 , and the answers were 0 people who answered strongly disagree $(0 \%)$, four people answered disagree (12, $5 \%), 24$ people who answered agreed $(75 \%)$, and five people who answered 
strongly agreed $(15.6 \%)$. This shows that almost all students agree that the existence of a module makes learning more practical and easier to apply.

Students gave to question 5, and the answers were 0 people who answered strongly disagree $(0 \%)$, one person answered disagree (3.1\%), 23 people who answered agreed (79.5\%), and eight people who answered strongly agreed (25\%). This shows that almost all students are familiar with and use the internet (website) in learning.

Question 6, students give the answers are 0 people who answer strongly disagree $(0 \%)$, three people who answer disagree $(9.4 \%), 21$ people answered agree $(65.5 \%)$, and eight people answered strongly agree $(25 \%)$. This shows that all students are interested in the learning process using the internet (website).

Question 7, students give the answers where 0 people answered strongly disagree $(0 \%), 15$ people answered disagree $(45.9 \%), 17$ people answered they agree $(53.1 \%)$, and one person answered strongly agree (3.1\%). This shows that most students are familiar with and have used electronic modules in the learning process.

Students gave to question 8 , and the answers were 0 people who answered strongly disagree $(0 \%)$, two people answered disagree $(6.3 \%), 24$ people answered they agreed (75\%), and seven people answered strongly agreed $(21.9 \%)$. This shows that almost all students are interested in the media presented interactively, such as images, videos, animations, and simulations, so it is easier to understand the teaching material.

\section{Conclusion}

The preliminary study concluded that both teachers and students found it difficult because of the COVID-19 outbreak, which required online learning. From the results of the analysis of the answers of teachers and students needed as alternative media in learning physics during the COVID-19 pandemic, it is necessary to develop a discovery-based physics learning e-module using professional flip PDF software that is integrated on the website.

\section{Acknowledgments}

Thanks to the Journal of Research in Science Education, Mataram University has provided a forum for sharing and exchanging knowledge. Thanks to Dr. Sarwanto, S. Pd., M.Si. and Ahmad Marzuki, S, Si., Ph.D., who guided and directed me to complete this research. Thank you to the principal and respondents who have been willing to be the subject of this research. Thank you to everyone who supported this research.

\section{References}

Abdin, A., Safiuddin, A., \& Kasman, K. (2021). Pemanfaatan Aplikasi Google Form Berbasis Online sebagai Alat Tes Tertulis Belajar Fisika pada Masa Pandemi Covid-19. Jurnal Penelitian Pendidikan Fisika, 6(1), 1-10. https://doi.org/10.36709/jipfi.v6i1.15408. [Indonesian]

Aththibby, A. R. (2015). Pengembangan Media Pembelajaran Fisika Berbasis Animasi Flash Topik Bahasan Usaha Dan Energi. Jurnal Pendidikan Fisika, 3(2). https://doi.org/10.24127/jpf.v3i2.238 [Indonesian]

Bakri, F., Rasyid, R., \& Mulyaningsih, R. D. A. (2015). Pengembangan Modul Fisika Berbasis Visual untuk Sekolah Menengah Atas (SMA). Jurnal Penelitian \& Pengembangan Pendidikan Fisika, 1(2), 67 - 74. doi: https://doi.org/10.21009/1.01211. [Indonesian]

Desmawati, R. (2018). Tahap Design Bahan Ajar Fisika SMA Terintegrasi Iman dan Takwa Berbasis Model Discovery Learning pada Materi Suhu. Natural Science Jurnal, 4(1), 516-526. https://doi.org/10.15548/nsc.v4i1.445 [Indonesia]

Hanna, D., Sutarto, \& Harijanto, A. (2016). Model Pembelajaran Tema Konsep Disertai Media Gambar pada Pembelajaran Fisika di SMA. Jurnal Pembelajaran Fisika. 5(1), 23-29. Retrieved from https://jurnal.unej.ac.id/index.php/JPF/article /view/3558. [Indonesian]

Lubis, I. L. (2009). Tingkatan Pemahaman Mahasiswa pada Konsep Fisika. Media Infotama. 498), 14-22. [Indonesian]

Matsun \& Saputri, F.D. (2020). Pengembangan E-Modul Fisika Berbantuan Whatsapp Sebagai Alternatif Pemebalajaran di Masa Pandemi Covid 19. ORBITA. Jurnal Hasil Kajian, Inovasi, dan Aplikasi Pendidikan Fisika. 6(2). Retrieved from: https://journal.ummat.ac.id/index.php/orbita/ article/view/3130 [Indonesian]

Mulyadi, E. (2020). Pembelajaran Daring Fisika Melalui Whatsapp, Google Form, dan Email dalam Capaian Presensi Aktif dan Hasil Belajar Peserta Didik. Ideguru: Jurnal Karya Ilmiah Guru. 5(1). [Indonesian]

Neizhela, A., \& Mosik. (2015). Meningkatan Hasil Belajar Melalui Pendekatan Kontekstual Dengan Metode Think Pair Share Materi Kalor Pada Siswa Smp. UPEJ Unnes Physics Education Journal, 
4(1). https://doi.org/10.15294/upej.v4i1.4737. [Indonesian]

Rahmiyati., Hidayat, M., \& Darmaji. (2018). Pengembangan Modul Elektronik dengan Pendekatan Saintifik Pokok Bahasan Hukum Termodinamika untuk SMA/MA Kelas XI. EduFisika : Jurnal Pendidikan Fisika. 3(1).

Saeri, M. (2020). Pembelajaran Fisika Dengan Video Rekam Layar Pada Masa Pandemi Covid-19 Untuk Mengoptimalkan Kemampuan Belajar Siswa Kelas XII-MIPA.1 Pokok Bahasan Listrik Dinamis SMA Negeri 2 Bangkalan. Karangan: Jurnal Bidang Kependidikan, Pembelajaran, Dan Pengembangan, 2(02), 26-32. Retrieved from https://ejournal.billfath.ac.id/index.php/karan gan/article/view/64.

Sari, P., Gunawan, G., \& Harjono, A. (2017). Penggunaan Discovery Learning Berbantuan Laboratorium Virtual pada Penguasaan Konsep Fisika Siswa. Jurnal Pendidikan Fisika dan Teknologi, 2(4), 176-182. doi:http://dx.doi.org/10.29303/jpft.v2i4.310. [Indonesian]

Sujanem, R. (2012). Pengembangan Modul Fisika Kontekstual Interaktif Berbasis Web untuk Meningkatkan Pemahaman Konsep dan Hasil Belajar Fisika Siswa SMA di Singaraja. Jurnal Nasional Pendidikan Teknik Informatika: Janapati, 1(2), $\quad$ 103-117. doi:http://dx.doi.org/10.23887/janapati.v1i2.98 25. [Indonesian]

Suryandari, W.A., \& Burhendi, A.C.F. (2020) Studi Pendahuluan Karakteristik Pembelajaran Online Fisika Selama Masa Pandemi Covid-19. JPD: Jurnal Pendidikan Dasar (Prosiding Seminar dan Diskusi Nasional Pendidikan Dasar). Retrieved from:

http://journal.unj.ac.id/unj/index.php/psdpd/ article/view/17752 [Indonesian]

Yusuf, M., \& Wulan, A. R. (2015). Penerapan Model Pembelajaran Discovery Learning Menggunakan Pembelajaran Tipe Shared dan Webbed untuk Meningkatkan Keterampilan Proses Sains. Jurnal Penelitian \& Pengembangan Pendidikan Fisika, 1(2), 19-26. doi: https://doi.org/10.21009/1.01204. [Indonesian] 